Article

\title{
Entrepreneurial Business Ties and New Venture Growth: The Mediating Role of Resource Acquiring, Bundling and Leveraging
}

\author{
Gang Wang ${ }^{1}$, Linwei $\mathrm{Li}^{2, *}$ and $\mathrm{Xu}$ Jiang $^{3} \mathrm{D}$ \\ 1 Economics and Management School, Wuhan University, Wuhan 430072, China; jiwuyou@foxmail.com \\ 2 School of Management, Xi'an University of Architecture and Technology, Xi'an 710055, China \\ 3 School of Management, Xi'an Jiaotong University, Xi'an 710049, China; jiangxuxu@163.com \\ * Correspondence: lilinwei1987@126.com
}

Received: 5 November 2018; Accepted: 2 January 2019; Published: 6 January 2019

\begin{abstract}
Adopting insights from a resource management perspective, this study investigates how entrepreneurs utilize their business ties to promote new venture growth. We propose a multiple mediator model in which different resource management processes (i.e., resource acquiring, resource bundling, and resource leveraging) act as critical mediating mechanisms. We undertook a two-stage survey design, and collected data during the period from 2013 to 2016. Drawing on a longitudinal sample of 229 new ventures in China, we tested the hypotheses through the optimal scaling regression (OSR) analysis. We find empirical support for the mediated effects of entrepreneurial business ties via resource bundling and resource leveraging to promote new venture growth. However, our results find the mediating effect of resource acquiring non-significant. These findings will deepen understanding of the role of entrepreneurial business ties in the new venture growth process and expand resource management perspective into the entrepreneurial field.
\end{abstract}

Keywords: entrepreneurial business ties; new venture growth; resource management

\section{Introduction}

New ventures are the most prevalent types of firms in emerging economies, which play a critical role in regional and national development [1,2]. New ventures are distinct from mature ones in terms of their resource scarcity and their newness, more likely to experience a high failure rate [3,4]. Indeed, new ventures may experience a high variance on the growth even in a short period. For example, Company OFO founded in 2015, the biggest bicycle-sharing company in China, has experienced a high growth in 2016 and 2017, but fell into deep crisis in 2018. Meanwhile, in spite of the high failure rate, there are some new ventures that successfully grow into big businesses in a short time, such as Xiaomi, Vivo, and many others in China. Thus, there is also a higher variance of growth rates for new ventures rather than established firms. Then why and how some new ventures can grow successfully represents a critical agenda [3].

Previous entrepreneurship literature has highly emphasized the importance and benefits of using entrepreneurial network ties because these ties can help new ventures acquire resources [5], capture opportunities [6], overcome information asymmetry and mitigate transaction costs [7], and implement the chosen strategies [6]. By definition, entrepreneurial network ties are a mixture of family, friendship, and business ties [8]. The dominant role of family ties has been widely acknowledged in entrepreneurial activities, especially in western countries [8,9]. However, some evidences indicate that the role of family might be not so critical in Chinese entrepreneurial ventures and practice [10]. Practically, numerous Chinese new ventures grow into big businesses with weak entrepreneurial 
family ties. For instance, Liu Qiangdong, the founder of the Company JD.com, was born into a poor peasant family. To the best of our knowledge, the growth of JD.com has benefited very little from Liu's family support. Instead, ties with other business partners (e.g., Tencent, Walmart) play a critical role in Liu's entrepreneurial activities. Meanwhile, considering the significant role of business ties in entrepreneurial activities [11], how entrepreneurial business ties promote new venture growth becomes an interesting topic.

Furthermore, according to the resource management logic suggested by Sirmon et al. [12], most of these entrepreneurial ties studies have overemphasized the initial resource acquiring phase, and largely neglected other deeper phases in resource management processes (e.g., resource bundling and resource leveraging). It seems more realistic to assume that entrepreneurial business ties affect new venture growth through a variety of resource management processes. Entrepreneurial business ties can help new ventures not only overcome resource scarcity, but also complement their weak capabilities and inexperience to enhance resource bundling and leveraging [12-14]. Therefore, overmuch attention about entrepreneurial business ties on the initial resource-acquiring phase, may limit our deeper understanding of the subsequent functions of entrepreneurial business ties in new ventures and the mechanisms through which they promote new venture growth, providing a piecemeal and unclear picture about how and why some new ventures can grow successfully.

Employing a resource management perspective [12-14], this study focuses on three resource management processes (i.e., resource acquiring, resource bundling and resource leveraging) and examines how they commonly act as critical mediating mechanisms between entrepreneurial business ties and new venture growth. While past studies on business ties have tended to focus on one antecedent of new venture growth at a time, such as opportunity capture [11] and resource acquiring [15], singling out a particular process that can lead to overstating the importance of that process as a mediating mechanism between ties and new venture growth. By contrast, examining the mediating roles of multiple resource management processes simultaneously may provide a more accurate and complete assessment of the mediating role of any one focal process.

By answering the question of how entrepreneurial business ties enhance new venture growth through multiple resource management processes, we hope our research can contribute to the entrepreneurial literature and resource management perspective in the following aspects. First, this study responds to the entrepreneurial notion that entrepreneurial research should pay more attention on how new venture grow occurs, instead of simply examining what promote new venture growth [3]. Second, by simultaneously investigating the mediating effects of multiple resource management processes, this study enriches our deeper understanding of the nature of entrepreneurial business ties. Finally, this study adds to our knowledge by applying resource management perspective in the entrepreneurial field. Although Sirmon et al. [12] suggest that resource management perspective may help open the black box of value creation, only limited scholars have applied this perspective in empirical research, especially in the context of new ventures $[14,16]$.

This paper is organized as follows: First, we develop our theoretic framework and research hypotheses based on resource management perspective. Next, we describe the longitudinal sample, and conduct the empirical procedures through MacKinnon's multiple mediation test. Finally, we provide a discussion of the empirical results and highlight their implications.

\section{Theoretical Background and Hypotheses}

\subsection{Theoretical Background}

New venture creation plays a critical role in the job creation and regional development [17]. However, very few new ventures can successfully evolve into large firms, and most of them fail and disappear in several years due to newness, smallness and resource scarcity [1]. With respect to its great importance and high failure rate, it attracts massive interest in the entrepreneurial literature to 
investigate what factors may affect new venture growth and why some new ventures grow better than others [18-20].

While general venture growth can be characterized as the increase of cash flow, net income, customer base, sales, employment, return on assets, overall efficiency of operations, and market share [21], the new venture literature suggests that the sales, employment, and market share can best capture the characteristics of new venture growth specifically [3]. Sales and mark share growth provide evidences that customers are increasingly accepting a new venture's products or services, while employment growth indicates a business increase sustainably [21]. Particularly, sales growth is the most commonly used variable to measure new venture growth [22].

Often based on an endogenous perspective, traditional entrepreneurship literature on new venture growth has explored the effects of new ventures' traits, such as entrepreneurs' characteristics $[19,23]$, firm resources [18,24], strategy [25], organizational structures and systems [26], open innovation projects [27], business model innovation [28], and entrepreneurial networks [6,7]. Some studies have also investigated the external driving forces of new venture growth, such as geographic location [20], institutional environment [29], sustainable venture capital [30], and industry context [31]. In spite of the critical role of network practices in entrepreneurial start-up processes, the relationship between entrepreneurial networks and subsequent venture growth has not been well explained [6].

Specifically, entrepreneurial networks contain a complex mixture of family, friendship, and business ties [8]. Although previous studies has shed much light on the dominant role of family ties in entrepreneurial networks $[8,9]$, some evidence suggests that the role of family may be not so critical for Chinese-speaking entrepreneurs as European ones [10,32]. For example, Au and Kwan find that, when warring about potential business-family conflicts, Chinese entrepreneurs tend to acquire resources from friends and other outside business actors rather than family members [10]. In view of the significant effect of business ties on new venture performance [11], we focus on entrepreneurs' business ties in their networks. We define entrepreneurial business ties as entrepreneurs' relationships with business partners, such as suppliers, customers, and peer companies. Through business ties, entrepreneurs can access precise product/service needs, good advices, emotional support, financial resources, and specialized knowledge [6,8,33], which can help new ventures overcome newness and smallness [3]. Moreover, recent entrepreneurial network research tends to employ a process approach to analysis the link between networking and entrepreneurial growth, such as Bourdieu's habitus [6]. This line of research serves as our starting point for constructing the theoretical model how resource management processes mediate the relationship between entrepreneurial business ties and new venture growth.

While some scholars suggest that possessing valuable, rare, inimitable, and difficult-to-substitute resources can help ventures build competitive advantage [34], resource management perspective argues that just possessing such resources is not enough for value creation, and does not guarantee the successful growth of a venture [13]. To realize successful growth, a venture, especially the new ones, must accumulate, combine and exploit resources through dynamic resource management processes [12]. Generally, resource management refers to "the comprehensive process of structuring the firm's resource portfolio, bundling the resources to build capabilities, and leveraging those capabilities with the purpose of creating and maintaining value for customers and owners" [12] (p. 7). Specifically, structuring is related to the process how a venture manages its resource portfolio (i.e., acquiring, accumulating, or divesting resources). Bundling is related to the process how a venture combines internal resources to extend existing capabilities or create new capabilities (i.e., stabilizing, enriching, or pioneering resources). Leveraging is related to the process how a venture utilizes its resource to satisfy customer demand and create wealth for shareholders (i.e., mobilizing, coordinating, and deploying) $[12,13]$. Through resource management processes, a venture can orchestrate resources to build competitive advantage and realize successful growth [12-14].

In this paper, we focus on three complementary yet interdependent processes: resource acquiring (one kind of resource structuring), resource bundling and resource leveraging [12]. We focus on resource acquiring rather than structuring based on the following reasons. First, previous studies 
on business ties put more emphasis on their effects on facilitate ventures to acquire resources from outside, instead of accumulating resources internally or divesting slack resources [35,36]. Second, new ventures are subject to resource scarcity, smallness, and newness, so it is difficult for them to develop resources internally and inappropriate to divest limited resources in the start-up period [3]. Specifically, resource acquiring is defined as the process how a new venture acquires resources from strategic factor markets [12]. Resource bundling refers to the process in which a new venture integrates resources acquired through various ways with its previous resources to make incremental improvements to existing capabilities or create new capabilities [12]. Resource leveraging reflects the process in which a new venture captures and exploits new opportunities, and further applies its resources to create value for customers and wealth for shareholders [12]. Through the above three resource management processes, we hope to open the black box of how entrepreneurial business ties promote new venture growth.

Overall, we develop a conceptual model illustrated in Figure 1.

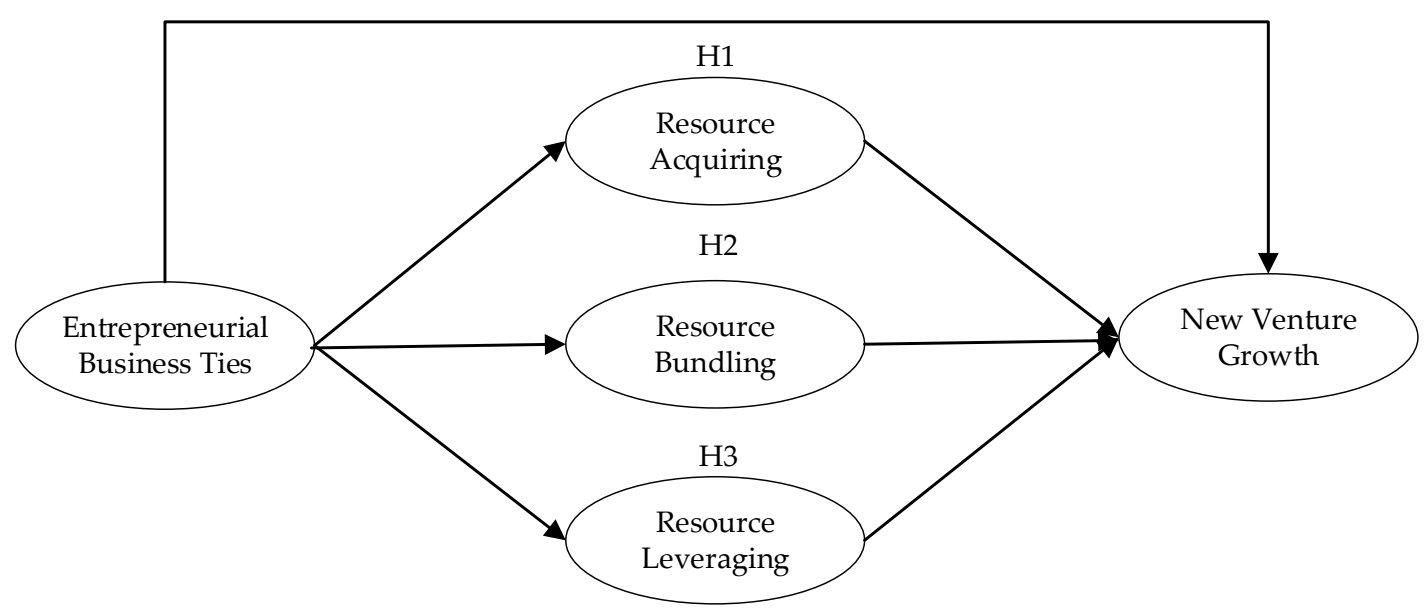

Figure 1. Conceptual model. Source: own study.

\subsection{Entrepreneurial Business Ties and New Venture Growth}

Entrepreneurial business ties will directly promote new venture growth for the following reasons. First, business ties, serving as a critical complement to the weak formal institutions, may help new ventures overcome institutional barriers [37]. The formal institutions in China, for example, which have not been well developed, are often characterized as incomplete intellectual property rights, instable institutions, and underdeveloped laws [38]. These weak and inefficient formal institutions can impose contradictory demands on new ventures [39], increase difficulties of identifying growth opportunities [11], create higher transaction costs [40], and make them difficult to survive, threatening their successful growth [29]. Business ties may help new ventures overcome this disadvantageous condition by completing market information, learning about competitors' behaviors, and identifying potential opportunities [29,41].

Second, entrepreneurial business ties can help a new venture acquire legitimacy. As a social judgment of acceptance, appropriateness, and desirability, legitimacy may decide whether an organization can survive and grow in the long run [42]. Mature or successful firms can possess legitimacy through sustained profitability, famous brand and great intangible assets [42]. Despite the importance of legitimacy, most new ventures suffer from a lack of legitimacy because of newness and smallness [43]. By building legitimacy, a new venture can achieve growth beyond survival [43]. And in the extant literature, a set of research has confirmed business ties as an important means of acquiring legitimacy $[36,44,45]$.

Third, entrepreneurial business ties can help a new venture grow successfully by capturing and commercializing opportunities. On the one hand, business ties help new ventures capture more 
market opportunities [11]. Business ties extend a new venture's boundaries, which help to find more boundary-spanning opportunities [46]. Business ties can also increase a new venture's sensitivity to the changing market condition and capture more market-trend opportunities, such as potential customer preferences and competitors' behaviors [41]. On the other hand, business ties help new ventures better commercialize these captured opportunities [47]. For example, relationships with customers help a new venture learn how to transmit materials to productions to satisfy the market opportunities; relationships with suppliers help a new venture realize the commercial value of the captured opportunities; relationships with peer companies help a new venture to develop pricing strategies, which will enhance the efficiency of commercializing opportunities.

Finally, entrepreneurial business ties per se stand for a kind of critical resource [48]. According to the Resource-based view (RBV), it may help new ventures build sustainable competitive advantage [34].

\subsection{Resource Management Processes as Mediating Mechanisms}

\subsubsection{The Mediating Role of Resource Acquiring}

Based on a resource management perspective, part of the reason why entrepreneurial business ties promote new venture growth is that they enhance a new venture's ability to acquire resources from outside during the acquisition phase. Entrepreneurial business ties enhance a new venture's resource acquiring efficiency through the following ways. First, business ties can directly help new ventures acquire valuable and scarce resources [5]. For example, in a guanxi-based country, Chinese managers are more willing to collaborate with familiar partners [38]. Thus, entrepreneurs with these business connections will obtain more collaboration opportunities and acquire useful resources from these partners more likely [48]. Second, the legitimacy acquired through entrepreneurial business ties also help a new venture win a good reputation, prestige and reliability, which will help the new venture indirectly acquire extra resources from nonfamiliar business actors [43].

The resources acquired through entrepreneurial business ties may help a new venture overcome resource scarcity, and improve their risk-taking capacity, prompting its growth. The first task for an entrepreneur to execute a growth plan is to collect enough resources [18]. However, most start-ups just possess limited resources, and often face the resource scarcity, which is recognized as a critical factor resulting in high failure rates [49]. Acquiring and possessing resources also ensure a new venture can invest necessary resources in high-risky technological innovation activities [50]. Otherwise, according to the resource dependency logic, possessing resources serves as a critical qualification for a new venture to build collaboration with others, which is critical to new venture growth [50]. Empirically, previous research has proven the value of resources in entrepreneurial activities [18,24].

In sum, resource acquiring processes enhanced by entrepreneurial business ties can help a new venture grow successfully. Therefore, we suggest:

Hypothesis 1. Resource acquiring mediates the positive relationship between entrepreneurial business ties and new venture growth.

\subsubsection{The Mediating Role of Resource Bundling}

Another reason why entrepreneurial business ties promote new venture growth is that these ties enable new ventures to better bundle and deploy different resources. Resource management research suggests that firms need integrate existing resources with acquired resources to realize a competitive advantage [14]. Entrepreneurial business ties can enhance new ventures' resource bundling process based on the following reasons. First, business ties help reduce the information asymmetry in the resource bundling process. Other firms tend to protect their knowledge and erect a technological edge to maintain their competitive advantage through some internal mechanisms, such as causal ambiguity, secrecy over resource attributes, and so on [51]. In this case, it is difficult for a new venture 
to integrate acquired resources with its existing resources because of its inexperience in resource management and other firms' knowledge protection. Business ties can help new ventures learn business partners' experience to supplement for its inexperience and enhance their understanding of resource attributes [36]. Thus, entrepreneurs with strong business ties can bundle resources better. Second, business ties help reduce the incompatibility between external resources and internal ones. For example, Human capital is considered to have critical influence on new venture growth [24]. However, there are often differences in human resource management activities among various companies, and thus human capital-typed resources are difficult to integrate [52]. Entrepreneurs with strong business ties can have a better understanding of their own and other companies' human capital resources, and deal with these problems better [36]. Otherwise, it is more likely that entrepreneurs with strong business ties can acquire complementary resources easier to make synergistic effect with its existing resources in the acquisition phase, since the entrepreneurs can learn more about the resource attributes [53].

Through the resource bundling processes improved by entrepreneurial business ties, a new venture can grow successfully. Resource bundling processes include resource stabilizing, enriching and pioneering [12]. First, the organizational inertia and path dependence caused by existing resource portfolio will make a venture difficult to make rapid strategic changes in a turbulent environment [16], which is critical for new venture growth [3]. Resource bundling processes help a new venture to orchestrate assets, build strategic flexibility, avoiding core rigidities and historical path dependence [54]. Second, through resources bundling processes, a new venture can improve its existing capabilities or creating new capabilities [13]. These capabilities can help a new venture overcome its inexperience in resource management, developing its technologies and products, and further raising its product quality and legitimacy [12]. Thus, through resource bundling processes, a new venture can be more proactive, and choose a right strategy quickly, ensuring its sustainable growth. Empirically, Yi et al. find that three kinds of resource bundling approaches (i.e., stabilizing, enriching, and pioneering) is critical for ventures to make rapid strategic change in a turbulent environment [16].

In short, resource bundling processes enhanced by entrepreneurial business ties can help a new venture grow successfully. Therefore, we suggest:

Hypothesis 2. Resource bundling mediates the positive relationship between entrepreneurial business ties and new venture growth.

\subsubsection{The Mediating Role of Resource Leveraging}

The third reason why entrepreneurial business ties promote new venture growth is that they help new ventures find how to leverage resources. Resource leveraging involves the processes how a new venture mobilizes, coordinates, and deploys resources [13]. The mobilizing process reflects how to identify necessary capabilities and design the capability configurations for market opportunities, whereas the coordinating and deploying processes emphasize how to implement a chosen leveraging strategy in an effective and efficient way [12]. Entrepreneurial business ties can enhance a new venture's resource leveraging processes through the above mechanisms. With respect to resource mobilizing, business ties help understand the nature of customer demand and technological capabilities, and identify the ambiguity between them, which is often an obstacle for new ventures to mobilize resources [12]. With respect to resource coordinating and deploying, business ties increase a new venture's understanding of knowledge about R\&D, engineering, marketing and distributing [55]. Thus, a new venture's internal cross-functional collaboration will become increasingly effective and efficient, which is critical for resource coordinating and deploying [12]. Furthermore, business ties can also increase entrepreneurs' tacit management knowledge and administrative skills, which play a significant role in these resource-leveraging processes [15]. 
Through the resource-leveraging processes, a new venture can grow successfully by adjusting and implementing strategies timely in turbulent environment. Previous research has confirmed the critical role of industry context in entrepreneurial activities [56]. For instance, quickly changing customer demand and rapid technological growth provide plentiful market opportunities. Thus, a new venture will realize a rapid and sustainable growth in a growing market [57]. Resource mobilizing helps an entrepreneur understand characteristics of the focal industry, and continually choose a growing market matched with its capability configurations [12]. Nevertheless, the successful growth of a new venture in growing markets still depend on the successful implement of chosen entrepreneurial strategies [58]. The resource coordinating and deploying ensure a new venture implement the chose strategies in an effective and efficient way [14].

As a result, resource leveraging processes enhanced by entrepreneurial business ties can help a new venture grow successfully. Therefore, we suggest:

Hypothesis 3. Resource leveraging mediates the positive relationship between entrepreneurial business ties and new venture growth.

\section{Method}

\subsection{Sample and Data Collection}

We used surveys of new ventures in China to test our hypotheses. There are at least two reasons why we choose China as the research context. First, entrepreneurs in China have a long historical tradition of using business ties when creating and operating new ventures [48]. Second, there is a high growth variance among new ventures in China [4]. Thus, Chinese new ventures provide an appropriate empirical context to investigate the mediation mechanisms why and how entrepreneurial business ties promote new venture growth.

Because of uneven economic reform, there are significant differences between the coastal region and inland areas on the entrepreneurial activities. Therefore, we collected data from both coastal regions and inland areas. In the coastal regions, we chose 3 municipalities (Beijing, Tianjin, and Shanghai) and 5 provinces (Liaoning, Hebei, Shandong, Jiangsu, and Guangdong); in the inland areas, we chose 7 provinces (Henan, Hubei, Hunan, Shanxi, Shaanxi, Gansu, and Sichuan). Using the company Yellow Pages, we randomly selected 40 new ventures from each province or municipality. We sampled new ventures (younger than eight years) [9,59], and excluded self-employed sole entrepreneurs since we focus on growth-oriented new ventures. Thus, we randomly selected 600 new ventures $\left(40^{*} 15\right)$ from China.

We first developed the English questionnaire based on a thorough, in-depth review of related literature and then translated it into a Chinese version with the assistance of four PhD students. We conducted a pilot test with 10 entrepreneurs experienced with Chinese business whose responses were not included in the final sample. During the process, six interviewers, including two assistant professors and four PhD students, checked each item with interviewees to ensure every question could be totally understood. Afterwards, all interviewers had a discussion for about $1 \mathrm{~h}$ and made some minor modifications. At last, we finalized our Chinese version of the questionnaire, and back-translated into English.

To test the causal link of the mediation model and avoid common method bias [60], we undertook a two-stage survey design. In Stage 1 (in February/September 2013), the trained interviewers contacted entrepreneurs of the above 600 new ventures by email or telephone, and explained the purpose of the survey and invited participation. Of the 600 firms contacted, 332 entrepreneurs agreed to participate. Finally, we contacted each identified respondent two times by telephone to secure a face-to-face interview. More than $80 \%$ of the interviews occurred at the entrepreneurs' offices. The average time for each interview was $30 \mathrm{~min}$. Entrepreneurs were asked to score their business ties, resource management processes, and other venture information according to their views of the items measuring 
them. All of the interviewers stayed in the offices to instruct the entrepreneurs on how to fill out the questionnaire and to clarify potential confusions that entrepreneurs might experience. In this stage, we also recorded these entrepreneurs' contacts. In Stage 2 (in June/July 2016), our interviewers contacted the above 332 entrepreneurs via telephone, and ask them to evaluate their venture growth condition, such as sales, market share and employment. We obtained 229 responses from these 332 entrepreneurs finally. Therefore, the effective response rate was 38.2 percent (229 out of 600).

To examine the potential nonresponse bias, we conducted three tests. First, in Stage 1, we compared the 332 respondents and the 268 nonrespondents on three variables (venture size, age, and ownership type) using $t$-tests. No difference was statistically significant at the significance level of 0.05 . Second, $t$-tests yielded no statistically significant differences regarding venture location or age between 229 respondents in 2016 and the 332 respondents in 2013. Third, in Stage 2, we divided the final sample into two subsamples according to the interview time, and found no significant difference between earlier 110 respondents and 119 later respondents on the scores of all question items at a $99 \%$ confidence interval. Therefore, nonresponse bias was not a major problem in the study [61]. Through the two-stage survey design, data on entrepreneurial network ties, three resource management processes, and other control variables were collected in one year, and data on new venture growth were collected in a lagged year. The independent variables and the dependent variable come from different sources. Thus, common method variance was also not a serious problem in this study [62].

Of the 229 new ventures, $73.4 \%$ are services firms, and $26.6 \%$ are manufacturing firms (see Table A2 in Appendix A). Geographically, $54.6 \%$ of the new ventures $(125 / 229)$ are located in coastal regions (Beijing, Tianjin, Shanghai, Liaoning, Hebei, Shandong, Jiangsu, and Guangdong), and 45.4\% are located in inland areas. The average age of the new ventures is 4.51 years. Specifically, 1 new venture $(0.4 \%)$ has been in existence for 2 years, 32 new ventures $(14.0 \%)$ for 3 years, 59 new ventures $(25.8 \%)$ for 4 years, 123 new ventures $(53.7 \%)$ for 5 years, and 14 new ventures $(6.1 \%)$ for 6 years.

\subsection{Measurement}

In Table 1, we provide the information about all the measurement items. We adapted the measures of all constructs from previous literature including word and sentence changes to enhance their readability in the Chinese context [4]. The independent variable, the three mediating variables, and the dependent variable were measured with a seven-point Likert scale from $1=$ strongly disagree to $7=$ strongly agree.

Drawing on business ties research in the context of China [11,41], we measured entrepreneurial business ties with three items. The scale indicates the extent to which entrepreneurs have maintained strong relationship with suppliers, customers, and peer companies. Based on the definition of resource management perspective [12-14], we developed the measurement scales for resource acquiring, resource bundling, and resource leveraging in the context of Chinese new ventures (see Table 1). New venture growth was measured by three items: the respondent was asked to rate the new venture's growth relative to its principal competitors over the last 3 years on sales, market share and employment [3].

We also controlled the following variables to account for alternative explanations. Ownership was coded 1 for state-owned ventures and 0 otherwise. Industry was coded 1 for manufacturing ventures and 0 for service ventures. Venture size was the natural log of the number of full-time employees. Venture age was measured by the number of years from the year of foundation to 2013. Venture development stage was measured by the four stages of the venture's product life cycle: 1 for introduction stage, 2 for growth stage, 3 for maturity stage, and 4 for recession stage. 
Table 1. Measurement validity assessments.

\begin{tabular}{lll}
\hline \multicolumn{1}{c}{ Constructs } & \multicolumn{1}{c}{ Measurement Items } & $\begin{array}{c}\text { Standardized } \\
\text { Loadings }\end{array}$ \\
\hline $\begin{array}{l}\text { Entrepreneurial } \\
\text { Business Ties }\end{array}$ & (1) Our entrepreneurs maintain strong relationship with suppliers. & 0.90 \\
$\alpha=0.76$ & (2) Our entrepreneurs maintain strong relationship with customers. & 0.87 \\
AVE $=0.68$ & (3) Our entrepreneurs maintain strong relationship with & 0.68 \\
\hline peer companies. & \\
Resource Acquiring & Our venture has acquired enough resources from outside: \\
$\alpha=0.88$ & (1) Advanced technologies, materials and equipment. & 0.90 \\
AVE $=0.81$ & (2) Financial resources. & 0.92 \\
\hline \multirow{2}{*}{ Resource Bundling } & (3) Human resources. & 0.87 \\
$\alpha=0.88$ & Through combining firm resources, & \\
AVE $=0.81$ & (1) We make minor increment improvements to existing capabilities. & 0.92 \\
\hline & (2) We extend current capabilities. & 0.91 \\
& (3) We create new capabilities. & 0.87 \\
Resource & (1) We are good at capturing new market opportunities. & 0.78 \\
Leveraging & (2) We are good at capturing new technological opportunities. \\
$\alpha=0.88$ & (3) We can identify the capabilities needed to support capability & 0.84 \\
AVE $=0.68$ & configurations necessary to exploit opportunities. & 0.81 \\
& (4) We can integrate identified capabilities into effective and efficient & 0.84 \\
& capability configurations. & \\
\hline New Venture & (5) We can use capability configurations to support chosen & 0.85 \\
Growth & leveraging strategies. & \\
$\alpha=0.86$ & In the past three years, our venture has experienced a sustainable \\
AVE $=0.78$ & growth on & \\
\hline
\end{tabular}

\subsection{Reliability and Construct Validity}

This study used SPSS20 to estimate the model's reliability and validity and to test the proposed hypotheses. We operationalized composite reliability using Cronbach's alpha. Typically, the literature agrees that reliability coefficients of 0.70 or higher are adequate [60]. As shown in Table 1, all alpha values are more than 0.70 . Therefore, these results suggest that our measurement satisfy the requirements of reliability.

We demonstrate the convergent validity by examining both the average variance extracted (AVE) and factor loadings. A factor loading of 0.70 or greater will indicate an adequate construct validity [63]. As shown in Table 1, among the 18 item loadings, only one is 0.69 , below this threshold, implying close relationships between the items and their respective constructs. An average variance extracted (AVE) of 0.50 or greater demonstrates that the construct as a whole shares more variance with its indicators compared with the error variance [63]. The calculations emerging from the AVE analysis are also provided in Table 1, and all surpass the recommended threshold for each construct.

We checked for discriminant validity by examining if the square root of AVE for each construct (within-construct variance) is greater than the correlations between constructs (between-construct variance) [63]. An examination of the values in the diagonal line in Table A1 (see Table A1 in Appendix A), which are the square root of the AVE for each construct, reveals that they are significantly greater than the correlation coefficients, indicating that the discriminant validity among the constructs was supported. 


\section{Empirical Results}

\subsection{Regression Results and Analyses}

We used the optimal scaling regression (OSR) analysis to test our models. The main reason is that, in our questionnaire, variables are from different categories. Specifically, all multi-item measures of independent, mediating, and dependent variables were based on a seven-point Likert scale, from 1 (strongly disagree) to 7 (strongly agree). Venture ownership, industry, and stage are nominal variables while venture size and age are numeric variables. Therefore, OSR is more suitable to deal with these categorical variables. In addition, OSR can iterate to find a best-regression model after using nonlinear transformation methods to transfer original categorical variables, which is also helpful to eliminate the problem of heteroscedasticity. Therefore, considering our survey approach and final sample, OSR is an efficient estimation technique [11,41]. We also used the White's test to check for heteroscedasticity, and results suggests that there was no heteroscedasticity in the data. We further conducted a multicollinearity diagnosis and all the variance inflation factors (VIF) were below 4.0, suggesting no multicollinearity concerns.

We conducted a three-step regression analysis to examine the multiple mediating effects of the three resource management processes (see Table 2) [62]. First, we examined the effects of the control variables on new venture growth by regressing new venture growth on these five variables (Model 1). Then, in Step 1, we added the independent variable to test the effects of entrepreneurial business ties on new venture growth. Results in Model 2 show that the independent variable of entrepreneurial business ties is positively related to new venture growth $(\beta=0.208, p<0.001)$, thus empirically supporting the direct effect of entrepreneurial business ties on new venture growth.

In Step 2, the first part was to examine the effects of entrepreneurial business ties on three resource management processes. Thus, we regressed resource acquiring, resource bundling, and resource leveraging on entrepreneurial business ties and the control variables to test their effects on multiple resource management processes. The results in Table 3 indicate that entrepreneurial business ties have a significant positive relationship with resource acquiring $(\beta=0.309, p<0.001)$, resource bundling ( $\beta=0.456, p<0.001)$, and resource leveraging $(\beta=0.495, p<0.001)$, providing empirical support for the basic effect of entrepreneurial business ties on these three resource management processes.

In the second part of Step 2, rather than three individual regression analysis for the three kinds of resource management processes, by conducting MacKinnon's multiple mediation test [64], we regressed new venture growth on three types of resource management processes simultaneously and the control variables in a single regression analysis. The results (Model 3) in Table 3 show that resource bundling $(\beta=0.162, p<0.01)$ and resource leveraging $(\beta=0.295, p<0.001)$ have significant positive effects on new venture growth while the effect of resource acquiring is not significant $(\beta=0.068, p>0.1)$. These results suggest that the effect of resource acquiring on new venture growth is nonsignificant when simultaneously controlling the effects of resource bundling and resource leveraging and the control variables.

In Step 3, we regressed new venture growth on entrepreneurial business ties, three resource management processes, and the control variables. Results in Model 4 show that the effect of entrepreneurial business ties is greatly reduced and become not significant $(\beta=0.089, p>0.1)$. Meanwhile, the effects of resource bundling $(\beta=0.152, p<0.05)$ and resource leveraging $(\beta=0.281$, $p<0.001$ ) on new venture growth remained significantly positive. These results suggest that resource bundling and resource leveraging mediate the relationships between entrepreneurial business ties and new venture growth, supporting $\mathrm{H} 2$ and $\mathrm{H} 3$. The mediating effect of resource acquiring (H1) is not supported.

We also conduct Sobel tests to assess the significance of mediation effects [65]. The Sobel test results confirm the mediating effect of resource bundling $(z=2.15, p<0.05)$ and of resource leveraging $(\mathrm{z}=3.55, p<0.001)$, but not of resource acquiring $(\mathrm{z}=0.88, p>0.10)$. 
Table 2. Mediation regression models.

\begin{tabular}{|c|c|c|c|c|c|c|c|}
\hline \multirow{2}{*}{ Variables } & \multicolumn{3}{|c|}{ Resource Management } & \multicolumn{4}{|c|}{ New Venture Growth } \\
\hline & $\begin{array}{l}\text { Resource } \\
\text { Acquiring }\end{array}$ & $\begin{array}{l}\text { Resource } \\
\text { Bundling }\end{array}$ & $\begin{array}{l}\text { Resource } \\
\text { Leveraging }\end{array}$ & Model 1 & Model 2 & Model 3 & Model 4 \\
\hline \multicolumn{8}{|l|}{ Controls } \\
\hline Ownership & -0.022 & 0.029 & 0.038 & 0.078 & 0.064 & 0.071 & 0.064 \\
\hline Industry & 0.096 & 0.091 & 0.085 & $-0.347^{* * *}$ & $-0.341^{* * *}$ & $-0.317^{* * *}$ & $-0.319^{* * *}$ \\
\hline Venture Size & $0.198^{* * *}$ & $0.096+$ & $0.226 * * *$ & 0.008 & 0.016 & -0.094 & -0.090 \\
\hline Venture Age & $-0.123+$ & 0.032 & 0.060 & $-0.117+$ & -0.087 & -0.078 & -0.072 \\
\hline Venture stage & $-0.151^{* * *}$ & $-0.132 *$ & 0.020 & $-0.126+$ & $-0.0127+$ & $-0.119+$ & $-0.121+$ \\
\hline Independent variable & & & & & & & \\
\hline $\begin{array}{c}\text { Entrepreneurial } \\
\text { business Ties } \\
\text { Mediating variable }\end{array}$ & $\begin{array}{c}0.309 * * * \\
(0.064)\end{array}$ & $\begin{array}{c}0.456^{* * *} \\
(0.062)\end{array}$ & $\begin{array}{c}0.495 * * * \\
(0.060)\end{array}$ & & $\begin{array}{c}0.208 * * * \\
(0.066)\end{array}$ & & $\begin{array}{c}0.089 \\
(0.066)\end{array}$ \\
\hline Resource Acquiring & & & & & & $\begin{array}{c}0.068 \\
(0.076)\end{array}$ & $\begin{array}{c}0.055 \\
(0.075)\end{array}$ \\
\hline Resource Bundling & & & & & & $\begin{array}{l}0.162 * * \\
(0.072)\end{array}$ & $\begin{array}{l}0.152 * \\
(0.072)\end{array}$ \\
\hline Resource Leveraging & & & & & & $\begin{array}{c}0.295^{* * *} \\
(0.075)\end{array}$ & $\begin{array}{c}0.281^{* * *} \\
(0.075)\end{array}$ \\
\hline$R^{2}$ & 0.183 & 0.243 & 0.304 & 0.145 & 0.177 & 0.272 & 0.278 \\
\hline Adjusted $R^{2}$ & 0.135 & 0.198 & 0.259 & 0.123 & 0.139 & 0.218 & 0.220 \\
\hline F Value & $3.764 * * *$ & $5.348^{* * *}$ & $6.732 * * *$ & $6.705^{* * *}$ & $4.640 * * *$ & $5.023 * * *$ & $4.808^{* * *}$ \\
\hline
\end{tabular}

Table 3. Additional mediation regression models.

\begin{tabular}{|c|c|c|c|c|c|c|}
\hline \multirow{2}{*}{ Variables } & \multicolumn{6}{|c|}{ New Venture Growth } \\
\hline & Model 3a & Model 4a & Model 3b & Model 4b & Model 3c & Model 4c \\
\hline \multicolumn{7}{|l|}{ Controls } \\
\hline Ownership & 0.083 & 0.077 & 0.060 & 0.059 & 0.077 & 0.067 \\
\hline Industry & $-0.339^{* * *}$ & $-0.297^{* * *}$ & $-0.342 * * *$ & $-0.321^{* * * *}$ & $-0.318^{* * *}$ & $-0.321^{* * *}$ \\
\hline Venture Size & -0.062 & -0.044 & -0.049 & 0.010 & $-0.099+$ & -0.096 \\
\hline Venture Age & -0.080 & -0.096 & -0.086 & -0.074 & -0.088 & -0.079 \\
\hline Venture Stage & -0.110 & 0.080 & -0.107 & -0.105 & $-0.143 *$ & -0.140 * \\
\hline Independent variable & & & & & & \\
\hline Entrepreneurial Business Ties & & $\begin{array}{c}0.199^{* * *} \\
(0.069)\end{array}$ & & $\begin{array}{l}0.137 * \\
(0.070)\end{array}$ & & $\begin{array}{l}0.123 * \\
(0.066)\end{array}$ \\
\hline \multicolumn{7}{|l|}{ Mediating variable } \\
\hline Resource Acquiring & $\begin{array}{c}0.235^{* * *} \\
(0.067)\end{array}$ & $\begin{array}{c}0.229^{* * *} \\
(0.070)\end{array}$ & & & & \\
\hline Resource Bundling & & & $\begin{array}{c}0.296^{* * *} \\
(0.064)\end{array}$ & $\begin{array}{c}0.257^{* * *} \\
(0.070)\end{array}$ & & \\
\hline Resource Leveraging & & & & & $\begin{array}{c}0.392 * * * \\
(0.064)\end{array}$ & $\begin{array}{c}0.351^{* * *} \\
(0.067)\end{array}$ \\
\hline $\mathrm{R}^{2}$ & 0.173 & 0.201 & 0.211 & 0.223 & 0.247 & 0.259 \\
\hline Adjusted $R^{2}$ & 0.135 & 0.150 & 0.170 & 0.174 & 0.212 & 0.216 \\
\hline F Value & $4.525^{* * *}$ & $3.993^{* * *}$ & $5.147^{* * *}$ & $4.544^{* * *}$ & $7.080 * * *$ & $6.090^{* * * *}$ \\
\hline
\end{tabular}

\subsection{Post Hoc Checks}

To further investigate the separate mediating effect of each resource management process, we also conduct individual regression analysis (See Table 3) for each resource management process in Stage 3 and the second part of Stage 2. The results in Table A1 seems different with Table 3. We further conduct Sobel tests to get detailed information about the separate mediation effects. The Sobel test results conform all these three separate mediating effects when examining separately, of resource acquiring $(\mathrm{z}=2.83, p<0.01)$, resource bundling $(\mathrm{z}=3.92, p<0.001)$ and resource leveraging $(\mathrm{z}=4.92, p<0.001)$. 


\section{Theoretical and Managerial Implications}

\subsection{Theoretical Implications}

This study advances research on new venture growth by applying a resource management perspective as an overarching framework. We explore the relationships among entrepreneurial business ties, multiple resource management processes, and new venture growth in an emerging economy. The empirical results reveals that multiple resource management processes, resource bundling and resource leveraging, act as critical mediating mechanisms that transmit the effects of entrepreneurial business ties to new venture growth. Our results provide contributions to the entrepreneurship literature and resource management perspective.

First of all, our study contributes to research on new venture growth by explaining how new ventures grow successfully through multiple resource management processes enhanced by entrepreneurial business ties. On one hand, we add knowledge about what factors promote new venture growth by introduce entrepreneurial business ties as the independent variable. While previous research on new venture growth has already paid much attention on entrepreneurs' family ties $[8,9]$, the role of business ties has not been extensively explored. On the other hand, by investigating the mediating mechanisms of multiple resource management processes, our study is an attempt to open the black box in which entrepreneurial business ties promote new venture growth. By doing this, this study responds to the entrepreneurial notion that entrepreneurial research should pay more attention on how new venture grow occurs, instead of simply examining what promote new venture growth [3].

Second, this study contributes to a resource management perspective by applying it into the entrepreneurship literature and providing empirical support. Although Sirmon and Hitt [13] suggest that a resource management perspective help open the black box of value creation, very limited scholars have applied this perspective in empirical research $[14,16]$. Our findings don't point toward a mediating role of resource acquiring when simultaneously controlling for the mediating effects of resource bundling and resource leveraging, which empirically support the resource management perspective that merely acquiring resources is insufficient for value creation unless such resources can be effectively bundled and leveraged $[12,14]$. Our empirical results also support the validity of Sirmon et al.'s framework [12] and confirm its function mechanism in the context of new ventures. The discriminant validity of three resource management processes and their distinct mediating mechanisms within the entrepreneurial business ties-new venture growth valid the usefulness of Sirmon et al.'s [12] distinction among three resource management processes: resource structuring process, resource bundling process and resource leveraging process.

Finally, our findings show that considering multiple mediating mechanisms simultaneously provides a more complete and clear understanding of how entrepreneurial business ties affect new venture growth than when these are studied individually. Previous business ties literature has confirmed some mediating roles in the context of general firms, such as resource acquisition [41]. In the context of new ventures, our study provides evidence that entrepreneurial business ties can and do affect new venture growth in different ways, through resource bundling and resource leveraging. These results reveal not only that there are multiple explanations about how entrepreneurial business ties affect new venture growth, but also that no one individually can completely explain this question. Furthermore, our findings also point out the risk of overestimating the mediating effects of any single resource management process when studying one at a time. For instance, while Wang et al. [41] have demonstrated a mediating role of resource acquiring in general firms, our results find the mediating effect of resource acquiring non-significant when simultaneously considering the other mediating effects of resource bundling and resource leveraging. These findings help us understand the nature of entrepreneurial business ties, by identifying the different mechanisms in which entrepreneurial business ties do affect new venture growth. 


\subsection{Managerial Implications}

Our study also makes critical implications for entrepreneurial activities in China. First of all, our empirical results have confirmed the critical role of entrepreneurial business ties in new venture growth. Compared with mature firms, new ventures face more resource scarcity, newness, smallness and inexperience, experiencing a high failure rate. This implies that entrepreneurs per se should pay more attention on utilizing their business ties to overcome this disadvantage, and further realizing new venture growth.

Second, our finding, that multiple resource management processes mediate the relationship between entrepreneurial business ties and new venture growth, implies that, in order to help new ventures grow successfully, entrepreneurs should actively improve internal resource management activities through their business ties. Specifically, our results provide empirical support for the mediating roles of just resource bundling and resource acquiring, but not simple resource acquiring. This seem to imply that entrepreneurs should realize that merely acquiring resources is insufficient for new venture growth, whereas bundling and leveraging resources are, if not more, at least of the same importance.

\subsection{Limitations and Future Directions}

Despite its obvious contributions, this study also has some limitations. First, we adopt resource management perspective [12] as our analytic framework, and find an interesting but meaningful phenomenon that the mediating role of resource acquiring is non-significant in multiple mediation procedures. Although it is valid and meaningful, limited empirical research has applied this framework $[14,16]$. We hope that this study stimulates further inquiry into the resource management processes of entrepreneurs, applying this multiple mediation analysis in other contexts, e.g., technological innovation, and corporate social responsibility. Second, due to our emphasis on the consequent multiple resource management processes, we only focus on entrepreneurial business ties. Given that existing studies have confirmed the dominant role of family ties in entrepreneurial growth (i.e., Anderson et al. [8]), future research can compare the effects of family and business ties on resource management processes. Future research can also further test whether the conclusions of this study are applicable in other types of entrepreneurial network ties. Third, our subjective measures may not be consistent with reality. Future research should collect objective indicators (e.g., official financial reports) to expand on our study. Finally, our research has not considered the contingency effects on the relationships between entrepreneurial business ties and resource management processes. Future research may explore potential moderators influencing the above relationships. For example, considering the importance of entrepreneur-specific factors in entrepreneurial activities, future research can examine whether self-employment moderates the effect of entrepreneurial business ties on resource management processes [66,67]. 


\section{Conclusions}

This study advances our theoretical and empirical understanding of why and how entrepreneurial business ties promote new venture growth. We highlight the importance of three resource management processes (i.e., resource acquiring, resource bundling and resource leveraging) and explain their distinct mediating mechanisms. The empirical results support the individual mediating effects of any one of resource management processes. Nevertheless, in multiple mediation procedures, we find that the mediating effect of simple resource acquiring is nonsignificant in the relationship between entrepreneurial business ties and new venture growth. It indicates that new ventures cannot grow successfully relying merely on resource acquiring, whereas resource bundling and leveraging play roles more critical in entrepreneurial activities. We hope this study can encourage more research that focuses on why and how some new ventures grow successfully.

Author Contributions: X.J. proposed the conceptualization of this study. G.W. and L.L. made the formal analysis and wrote the paper together.

Funding: This research was funded by the National Natural Science Foundation of China (71402128; 71772148; 71572134).

Conflicts of Interest: The authors declare no conflicts of interest. 


\section{Appendix A}

Table A1. Descriptive statistics and correlation matrix.

\begin{tabular}{|c|c|c|c|c|c|c|c|c|c|c|c|c|}
\hline Variables & Mean & s.d. & 1 & 2 & 3 & 4 & 5 & 6 & 7 & 8 & 9 & 10 \\
\hline 1. Ownership & 0.23 & 0.42 & 1 & & & & & & & & & \\
\hline 2. Industry & 0.27 & 0.44 & -0.067 & 1 & & & & & & & & \\
\hline 3. Venture Size ${ }^{a}$ & 4.81 & 1.53 & 0.092 & 0.065 & 1 & & & & & & & \\
\hline 4. Venture Age & 4.51 & 0.83 & -0.093 & 0.092 & $0.157 *$ & 1 & & & & & & \\
\hline 5. Venture Development Stage & 2.49 & 0.56 & 0.036 & $0.120+$ & $0.137 *$ & $0.163 *$ & 1 & & & & & \\
\hline 6. Entreprenurial Business Ties & 4.76 & 1.08 & -0.084 & -0.054 & -0.050 & -0.042 & -0.083 & 0.82 & & & & \\
\hline 7. Resource Acquiring & 5.36 & 1.10 & 0.017 & $-0.122+$ & $0.143 *$ & -0.044 & $-0.138 *$ & $0.360 * * *$ & 0.90 & & & \\
\hline 8. Resource Bundling & 4.88 & 1.14 & -0.003 & -0.071 & 0.041 & -0.004 & -0.054 & $0.458 * * *$ & $0.439 * * *$ & 0.90 & & \\
\hline 9. Resource Leveraging & 4.88 & 1.07 & -0.018 & -0.077 & $0.233^{* * *}$ & 0.064 & -0.006 & $0.429 * * *$ & $0.528^{* * *}$ & $0.533 * * *$ & 0.82 & \\
\hline 10. New Venture Growth & 4.87 & 1.26 & -0.040 & $0.124+$ & 0.044 & -0.030 & -0.002 & $0.270 * * *$ & $0.274^{* * *}$ & $0.340 * * *$ & $0.390 * * *$ & 0.88 \\
\hline
\end{tabular}

$n=229{ }^{\text {a }}$ Log-transformed. $+p<0.10{ }^{*} p<0.05,{ }^{* * *} p<0.001$. 
Table A2. Profiles of the Sample ventures $(N=229)$.

\begin{tabular}{|c|c|c|}
\hline Sample Characteristics & Number of Ventures & Percentage $(\%)$ \\
\hline \multicolumn{3}{|l|}{ 1. Venture Age } \\
\hline 2 years & 1 & 0.4 \\
\hline 3 years & 32 & 14 \\
\hline 4 years & 59 & 25.8 \\
\hline 5 years & 123 & 53.7 \\
\hline 6 years & 14 & 6.1 \\
\hline \multicolumn{3}{|l|}{ 2. Geographic Location } \\
\hline Coastal regions & 125 & 54.6 \\
\hline Beijing & 13 & 5.7 \\
\hline Tianjin & 11 & 4.8 \\
\hline Shanghai & 21 & 9.2 \\
\hline Liaoning & 10 & 4.4 \\
\hline Hebi & 21 & 9.2 \\
\hline Shandong & 14 & 6.1 \\
\hline Jiangsu & 17 & 7.4 \\
\hline Guangdong & 18 & 7.9 \\
\hline Inland areas & 104 & 45.4 \\
\hline Henan & 23 & 10.0 \\
\hline Hubei & 20 & 8.7 \\
\hline Hunan & 10 & 4.4 \\
\hline Shanxi & 8 & 3.5 \\
\hline Shaanxi & 27 & 11.8 \\
\hline Gansu & 7 & 3.1 \\
\hline Sichuan & 9 & 3.9 \\
\hline \multicolumn{3}{|l|}{ 3. Ownership } \\
\hline State owned & 52 & 22.7 \\
\hline Others & 177 & 77.3 \\
\hline \multicolumn{3}{|l|}{ 4. Industry } \\
\hline Manufacturing & 61 & 26.6 \\
\hline Food & 13 & 5.7 \\
\hline Textiles & 8 & 3.5 \\
\hline Electronics & 19 & 8.3 \\
\hline Chemicals & 7 & 3.1 \\
\hline Furniture & 14 & 6.1 \\
\hline Services & 168 & 73.4 \\
\hline Sales & 44 & 19.2 \\
\hline Services of motor vehicles & 24 & 10.5 \\
\hline Transport & 26 & 11.4 \\
\hline Advertising & 39 & 17.0 \\
\hline Tourism & 35 & 15.3 \\
\hline
\end{tabular}

\section{References}

1. Barringer, B.R.; Jones, F.F.; Neubaum, D.O. A quantitative content analysis of the characteristics of rapid-growth firms and their founders. J. Bus. Ventur. 2005, 20, 663-687. [CrossRef]

2. Acs, Z.J.; Armington, C. Employment growth and entrepreneurial activity in cities. Reg. Stud. 2004, 8, 911-927. [CrossRef]

3. Gilbert, B.A.; McDougall, P.P.; Audretsch, D.B. New Venture Growth: A Review and Extension. J. Manag. 2006, 32, 926-950. [CrossRef]

4. Li, H.; Zhang, Y. The role of managers' political networking and functional experience in new venture performance: Evidence from China's transition economy. Strateg. Manag. J. 2007, 28, 791-804. [CrossRef]

5. Jack, S.L.; Dodd, S.D.; Anderson, A.R. Social Structures and Entrepreneurial Networks: The Strength of Strong Ties. Int. J. Entrep. Innov. 2004, 5, 107-120. [CrossRef]

6. Anderson, A.R.; Dodd, S.D.; Jack, S. Network practices and entrepreneurial growth. Scand. J. Manag. 2010, 26, 121-133. [CrossRef] 
7. Zhang, J.; Soh, P.; Wong, P. Direct ties, prior knowledge, and entrepreneurial resource acquisitions in China and Singapore. Int. Small Bus. J. 2011, 29, 170-189. [CrossRef]

8. Anderson, A.R.; Jack, S.L.; Drakopoulou Dodd, S. The Role of Family Members in Entrepreneurial Networks: Beyond the Boundaries of the Family Firm. Fam. Bus. Rev. 2005, 18, 135-154. [CrossRef]

9. Arregle, J.L.; Batjargal, B.; Hitt, M.A.; Webb, J.W.; Miller, T.; Tsui, A.S. Family Ties in Entrepreneurs' Social Networks and New Venture Growth. Entrep. Theory Pract. 2015, 39, 313-344. [CrossRef]

10. Au, K.; Kwan, H.K. Start-Up Capital and Chinese Entrepreneurs: The Role of Family. Entrep. Theory Pract. 2009, 33, 889-908. [CrossRef]

11. Li, Y.; Chen, H.; Liu, Y.; Peng, M.W. Managerial ties, organizational learning, and opportunity capture: A social capital perspective. Asia Pac. J. Manag. 2014, 31, 271-291. [CrossRef]

12. Sirmon, D.G.; Hitt, M.A.; Ireland, R.D. Managing Firm Resources in Dynamic Environments to Create Value: Looking Inside the Black Box. Acad. Manag. Rev. 2007, 32, 273-292. [CrossRef]

13. Sirmon, D.G.; Hitt, M.A. Managing resources: Linking unique resources, management, and wealth creation in family firms. Entrep. Theory Pract. 2003, 27, 339-358. [CrossRef]

14. Sirmon, D.G.; Gove, S.; Hitt, M.A. Resource Management in Dyadic Competitive Rivalry: The Effects of Resource Bundling and Deployment. Acad. Manag. J. 2008, 51, 919-935. [CrossRef]

15. Leung, A.; Zhang, J.; Wong, P.K.; Foo, M.D. The use of networks in human resource acquisition for entrepreneurial firms: Multiple "fit" considerations. J. Bus. Ventur. 2006, 21, 664-686. [CrossRef]

16. Yi, Y.; Li, Y.; Hitt, M.A.; Liu, Y.; Wei, Z. The influence of resource bundling on the speed of strategic change: Moderating effects of relational capital. Asia Pac. J. Manag. 2016, 33, 435-467. [CrossRef]

17. Acs, Z.J.; Armington, C. Entrepreneurship, Geography, and American Economic Growth; Cambridge University Press: Cambridge, UK, 2006.

18. Arthurs, J.D.; Busenitz, L.W. Dynamic capabilities and venture performance: The effects of venture capitalists. J. Bus. Ventur. 2006, 21, 195-215. [CrossRef]

19. Baum, J.R.; Locke, E.A. The relationship of entrepreneurial traits, skill, and motivation to subsequent venture growth. J. Appl. Psychol. 2004, 89, 587. [CrossRef]

20. Folta, T.B.; Cooper, A.C.; Baik, Y. Geographic cluster size and firm performance. J. Bus. Ventur. 2006, 21, 217-242. [CrossRef]

21. Murphy, G.B.; Trailer, J.W.; Hill, R.C. Measuring performance in entrepreneurship research. J. Bus. Res. 1996, 36, 15-23. [CrossRef]

22. Weinzimmer, L.G.; Nystrom, P.C.; Freeman, S.J. Measuring Organizational Growth: Issues, Consequences and Guidelines. J. Manag. 1998, 24, 235-262. [CrossRef]

23. Hmieleski, K.M.; Baron, R.A. Entrepreneurs' Optimism and New Venture Performance: A Social Cognitive Perspective. Acad. Manag. J. 2009, 52, 473-488. [CrossRef]

24. Cardon, M.S. Contingent labor as an enabler of entrepreneurial growth. Hum. Resour. Manag. 2003, 42, 57-373. [CrossRef]

25. Baum, J.R.; Locke, E.A.; Smith, K.G. A Multidimensional Model of Venture Growth. Acad. Manag. J. 2001, 44, 292-303. [CrossRef]

26. Savarese, M.F.; Orsi, L.; Belussi, F. New venture high growth in high-tech environments. Eur. Plan. Stud. 2016, 24, 1937-1958. [CrossRef]

27. Yoon, B.; Shin, J.; Lee, S. Open innovation projects in SMEs as an engine for sustainable growth. Sustainability 2016, 8, 146. [CrossRef]

28. Zhang, H.; Sun, X.; Lyu, C. Exploratory Orientation, Business Model Innovation and New Venture Growth. Sustainability 2018, 10, 56. [CrossRef]

29. Batjargal, B.; Hitt, M.A.; Tsui, A.S.; Arregle, J.; Webb, J.W.; Miller, T.L. Institutional Polycentrism, Entrepreneurs' Social Networks, and New Venture Growth. Acad. Manag. J. 2012, 56, 1024-1049. [CrossRef]

30. Bocken, N.M.P. Sustainable venture capital-catalyst for sustainable start-up success? J. Clean Prod. 2015, 108, 647-658. [CrossRef]

31. Bamford, C.E.; Dean, T.J.; McDougall, P.P. An examination of the impact of initial founding conditions and decisions upon the performance of new bank start-ups. J. Bus. Ventur. 2000, 15, 253-277. [CrossRef]

32. Thomas, H.; Au, K.; Leung, L.; Suen, B.; Yip, S.; Lo, R. Global entrepreneurship monitor: Hong Kong 2007. Retrieved August 2007, 30, 2008. 
33. Jing, Z.; Soh, P.; Wong, P. Entrepreneurial Resource Acquisition through Indirect Ties: Compensatory Effects of Prior Knowledge. J. Manag. 2009, 36, 511-536. [CrossRef]

34. Barney, J.B. Resource-based theories of competitive advantage: A ten-year retrospective on the resource-based view. J. Manag. 2001, 27, 643-650. [CrossRef]

35. Greve, A.; Salaff, J.W. Social Networks and Entrepreneurship. Entrep. Theory Pract. 2003, 28, 1-22. [CrossRef]

36. Hoang, H.; Antoncic, B. Network-based research in entrepreneurship: A critical review. J. Bus. Ventur. 2003, 18, 165-187. [CrossRef]

37. Lechner, C.; Dowling, M. Firm networks: External relationships as sources for the growth and competitiveness of entrepreneurial firms. Entrep. Reg. Dev. 2003, 15, 1-26. [CrossRef]

38. Xin, K.K.; Pearce, J.L. Guanxi: Connections as Substitutes for Formal Institutional Support. Acad. Manag. J. 1996, 39, 1641-1658. [CrossRef]

39. Pache, A.; Santos, F. When Worlds Collide: The Internal Dynamics of Organizational Responses to Conflicting Institutional Demands. Acad. Manag. Rev. 2010, 35, 455-476. [CrossRef]

40. Sobel, R.S.; Coyne, C.J. Cointegrating Institutions: The Time-Series Properties of Country Institutional Measures. J. Law Econ. 2011, 54, 111-134. [CrossRef]

41. Wang, G.; Jiang, X.; Yuan, C.; Yi, Y. Managerial ties and firm performance in an emerging economy: Tests of the mediating and moderating effects. Asia Pac. J. Manag. 2013, 30, 537-559. [CrossRef]

42. Suchman, M.C. Managing Legitimacy: Strategic and Institutional Approaches. Acad. Manag. Rev. 1995, 20, 571-610. [CrossRef]

43. Zimmerman, M.A.; Zeitz, G.J. Beyond Survival: Achieving New Venture Growth by Building Legitimacy. Acad. Manag. Rev. 2002, 27, 414-431. [CrossRef]

44. Stam, W.; Arzlanian, S.; Elfring, T. Social capital of entrepreneurs and small firm performance: A meta-analysis of contextual and methodological moderators. J. Bus. Ventur. 2014, 29, 152-173. [CrossRef]

45. Shane, S.; Cable, D. Network Ties, Reputation, and the Financing of New Ventures. Manage. Sci. 2002, 48, 364-381. [CrossRef]

46. Ballou, R.H.; Gilbert, S.M.; Mukherjee, A. New Managerial Challenges from Supply Chain Opportunities. Ind. Mark. Manag. 2000, 29, 7-18. [CrossRef]

47. Hite, J.M. Evolutionary Processes and Paths of Relationally Embedded Network Ties in Emerging Entrepreneurial Firms. Entrep. Theory Pract. 2004, 29, 113-144. [CrossRef]

48. Peng, M.W.; Luo, Y. Managerial Ties and Firm Performance in a Transition Economy: The Nature of a Micro-Macro Link. Acad. Manag. J. 2000, 43, 486-501. [CrossRef]

49. Brush, C.G.; Greene, P.G.; Hart, M.M. From initial idea to unique advantage: The entrepreneurial challenge of constructing a resource base. Acad. Manag. Perspect. 2001, 15, 64-78. [CrossRef]

50. Li, H.; Atuahene-Gima, K. Product Innovation Strategy and the Performance of New Technology Ventures in China. Acad. Manag. J. 2001, 44, 1123-1134. [CrossRef]

51. Lippman, S.A.; Rumelt, R.P. Uncertain Imitability: An Analysis of Interfirm Differences in Efficiency under Competition. Bell J. Econ. 1982, 13, 418-438. [CrossRef]

52. Hurmelinna-Laukkanen, P.; Puumalainen, K. Nature and dynamics of appropriability: Strategies for appropriating returns on innovation. $R$ D Manag. 2007, 37, 95-112. [CrossRef]

53. Boisot, M.; Child, J. From Fiefs to Clans and Network Capitalism: Explaining China's Emerging Economic Order. Adm. Sci. Q. 1996, 41, 600-628. [CrossRef]

54. Leonard-Barton, D. Core capabilities and core rigidities: A paradox in managing new product development. Strateg. Manag. J. 1992, 13, 111-125. [CrossRef]

55. Dong, M.C.; Li, C.B.; Tse, D.K. Do Business and Political Ties Differ in Cultivating Marketing Channels for Foreign and Local Firms in China? J. Int. Market. 2013, 21, 39-56. [CrossRef]

56. Kiss, A.N.; Barr, P.S. New venture strategic adaptation: The interplay of belief structures and industry context. Strateg. Manag. J. 2014, 36, 1245-1263. [CrossRef]

57. Castrogiovanni, G.J. Environmental Munihcence; A Theoretical Assessment. Acad. Manag. Rev. 1991, 16, 542-565. [CrossRef]

58. Olson, P.D.; Bokor, D.W. Strategy process-content interaction: Effects on growth perf. J. Small Bus. Manag. 1995, 33, 34 .

59. Zhang, Y.; Li, H. Innovation search of new ventures in a technology cluster: The role of ties with service intermediaries. Strateg. Manag. J. 2009, 31, 88-109. [CrossRef] 
60. Slater, S.F.; Atuahene-Gima, K. Conducting survey research in strategic management. In Research Methodology in Strategy and Management; Emerald Group Publishing Limited: Bingley, UK, 2004; pp. 227-249.

61. Armstrong, J.S.; Overton, T.S. Estimating nonresponse bias in mail surveys. J. Mark. Res. 1977, $396-402$. [CrossRef]

62. Podsakoff, N.P. Common method biases in behavioral research: A critical review of the literature and recommended remedies. J. Appl. Psychol. 2003, 88, 879-903. [CrossRef]

63. Fornell, C.; Larcker, D.F. Evaluating Structural Equation Models with Unobservable Variables and Measurement Error. J. Mark. Res. 1981, 18, 39-50. [CrossRef]

64. Rose, J.S.; Chassin, L.; Presson, C.C.; Sherman, S.J. Contrasts in Multiple M ediator Models. In Multivariate Applications in Substance Use Research; Psychology Press: New York, NY, USA, 2000; pp. 155-174.

65. Sobel, M.E. Asymptotic confidence intervals for indirect effects in structural equation models. Sociol. Methodol. 1982, 13, 290-312. [CrossRef]

66. Dvouletý, O.; Mühlböck, M.; Warmuth, J.; Kittel, B. 'Scarred' young entrepreneurs. Exploring young adults' transition from former unemployment to self-employment. J. Youth Stud. 2018, 21, 1159-1181. [CrossRef]

67. Dvouletý, O. Determinants of Self-employment with and Without Employees: Empirical Findings from Europe. Int. Rev. Entrep. 2018, 16, 405-426.

(C) 2019 by the authors. Licensee MDPI, Basel, Switzerland. This article is an open access article distributed under the terms and conditions of the Creative Commons Attribution (CC BY) license (http:/ / creativecommons.org/licenses/by/4.0/). 